Orissa Journal of Commerce

Vol. 42, Issue 3, July-September 2021

ISSN: 0974-8482

(C) OJC India. All Right Reserved

URL: www.ojcoca.org

DOI: https://doi.org/10.54063/ojc.2021.v42i03.01

\title{
Market Volatility and Causal Relationship among BRICS Stock Markets
}

\author{
Soumya Ganguly ${ }^{1 *}$ and Amalendu Bhunia ${ }^{2}$ \\ ${ }^{1}$ State Aided College Teacher, Department of Commerce, Barrackpore Rastraguru Surendranath College, Barrackpore, \\ West Bengal. E-mail: soumyaganguly2008@yahoo.com \\ ${ }^{2}$ Professor, Department of Commerce, University of Kalyani, Kalyani, West Bengal. E-mail: bbunia.amalendu@gmail.com \\ ${ }^{*}$ Corresponding Author
}

To cite this paper

Ganguly, S., \& Bhunia, A. (2021). Market Volatility and Causal

Relationship among BRICS Stock Markets. Orissa Journal of Commerce. 42(3), 1-14.

Keywords

BRICS, Stock markets, Volatility, GARCH models, VECM

JEL Classification

C32. E37, E44, G10

\begin{abstract}
This study examines the stock market volatility and causal connection among BRICS stock markets. This research uses data from November 18, 2019 to February 1, 2021. This study employed descriptive statistics, correlation analysis, ADF unit-root tests, GARCH models, and the VECM test. The JarqueBera statistics' likelihood shows that certain stock markets are not regularly distributed. During the outbreak of COVID-19 pandemic, correlation studies revealed that all BRICS stock markets were favourably associated with one another. The GARCH test results substantiates that the selected stock markets were extremely volatile throughout the research period other than South Africa stock market. The research also indicates that the BRICS markets have no leverage impact. The findings of the VECM tests divulge that while there is no noteworthy long-term causality among BRICS stock market, however, there exist a short-run causality between, other than Brazilian stock market.
\end{abstract}

\section{Introduction}

The stock market operations of BRICS have seen significant development in recent years. It was predicted that the BRICS member countries' growth rate would accelerate in the near future, possibly exceeding the combined growth rate of European countries and the United States by 2030. BRICS member countries currently comprise $16 \%$ of global imports as well as $19 \%$ of global exports (Larionova, 2020). Another development made by the BRICS for the improvement of the international financial system by the introduction of BRICS Contingent Reserve Arrangement with 100 billion US dollars and also by the formation of a New Development Bank.

The world economy observed volatility for long years back due to so many reasons. One of the most significant causes of volatility is the entrance of various diseases and pandemics into our society, such as MERS, Spanish flu, SARS, Ebola, Zika, etc (Cambre, 2020; Nathan, 2020). Because of the Coronavirus epidemic, all of the BRICS member countries' stock markets are volatile, as seen in the 

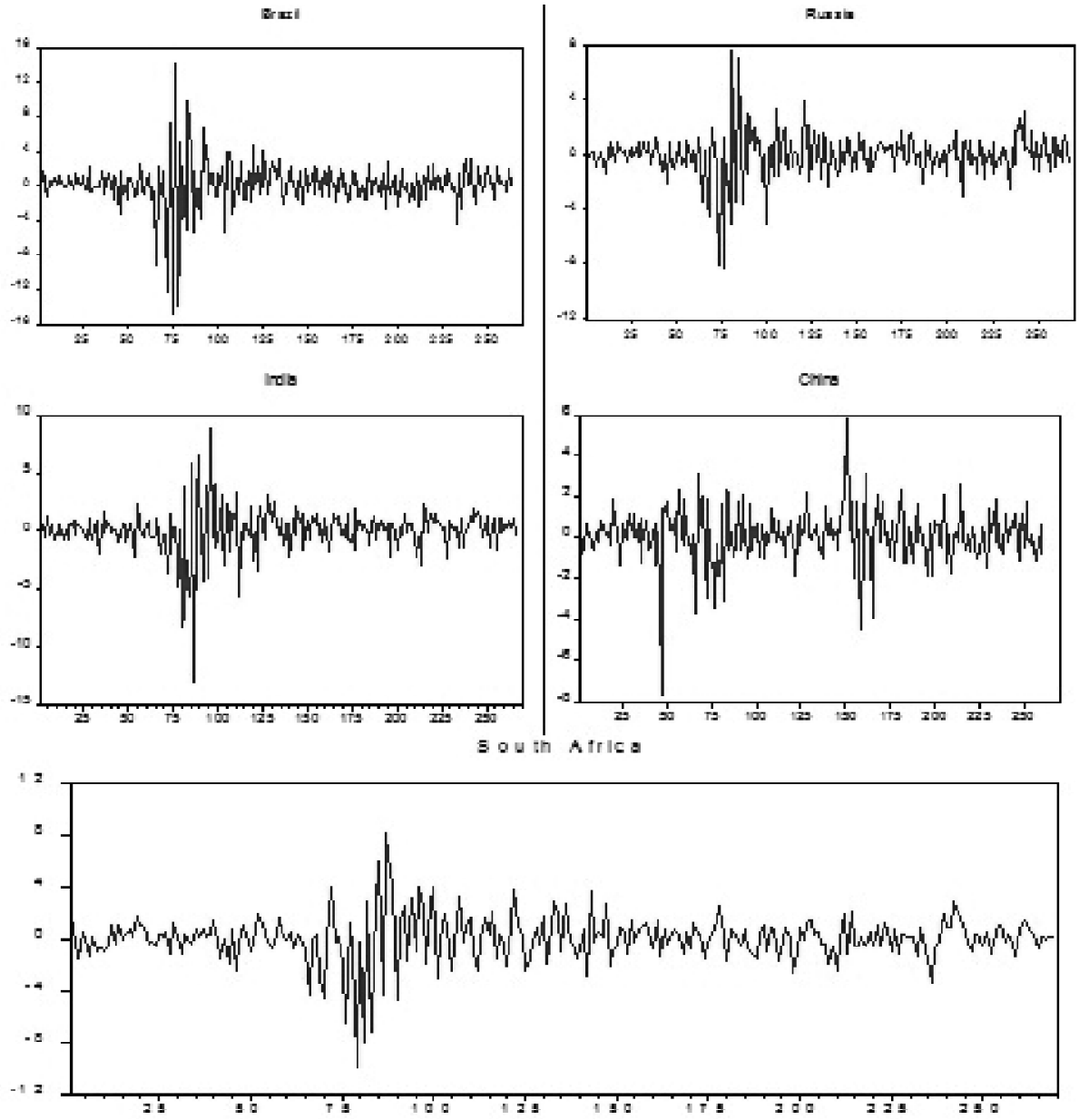

Figure 1: Return Graph of BRICS Country during COVID-19 Outbreak

Source: Authors' Calculation through EViews

graph below. The volatility in stock market returns is particularly high in the early days of an epidemic, followed by steady volatility in certain stock markets.

The CFO of the New Development Bank opined, if this economic slowdown due to the COVID19 pandemic stays over a longer period of time it will ultimately lead to economic growth in a very dangerous situation. According to the vice-president, the member countries of the BRICS nation are taking some comprehensive measures to safeguard their economic condition during this phase of the COVID-19 pandemic (Hashmi, 2020). According to the International Monetary Fund, a reduction of $4.9 \%$ in the growth rate will be observed in the world's market during 2020 due to the outbreak of COVID-19 and during 2021 it is anticipated to regain the growth rate by $5.4 \%$. The first patient of 
COVID-19 was traced on $17^{\text {th }}$ November 2019 (Bryner, 2020). Most of the affected countries throughout the world entered into a complete or partial lockdown phase due to the outbreak of the coronavirus. This process definitely helps to equip the respective countries to fight against the newly formed virus. But on the contrary, lockdown impacted the economy in a very terrible way due to the stoppage of production and interruption in the distribution channel raising a question of precedence with livelihood and life (Bakhshi and Chaudhary, 2020).

\section{Literature Review and Gap Analysis}

Many previous researchers evaluated the stock market volatility of both developed and developing economies, both during emergencies and in regular circumstances. Several of these studies noted the presence of uncertainty in stock market returns in certain nations, but just a handful did not mention it. Earlier research that attempted to determine the connection and volatility in various nations' stock markets have been addressed in this section.

A negative association on the selected airline firms was discovered in Loh's (2006) study, which used daily data from December 1, 2002 to July 5, 2003. The study also discovered that during the SARS pandemic, the stock market volatility of Singapore was substantially higher. Olowe (2009) used the ARCH family model to investigate the leverage impact as well as stock market volatility of Nigeria. In this study, the researcher exercised daily data from January 4, 2004 to March 2, 2009 to observe the continuity of volatility and connection. In the study of Neokosmidis (2009), a significant level of volatility was noticed in the four most important stock markets. The study employed ARCH family models to analyse the data between March 2003 and March 2009. According to Joshi’s (2010) study, there is a lot of unpredictability. The study looked at daily data between January 1 (2005) and May 12 (2009) using GARCH family models to determine the volatility of the Indian and Chinese share markets. Ichev and Marinc (2018) examined the instability of the US and West African capital markets and observed that it was increased significantly as a result of the Ebola outbreak.

Using the data since the stock market crisis of 1987, Wong et al. (2004) has confirmed the interdependencies across different developing and developed stock markets, which has been enhanced since the Asian Financial Crisis 1997. Joshi (2013) analysed to see how the BRIC stock markets fared pre- and post-global financial crisis and discovered a long-term connection from the stock market of India to the Russian and Chinese stock markets using the Engle-Granger cointegration test. Sharma et al. (2013) observed the interdependencies across the BRICS stock markets based on the data from April 1 (2005) to March 31 (2010) using causality test, VAR model, and variance decomposition test. Tiwari et al. (2013) used daily data from 9 Asian nations from January 4, 2005 to February 28, 2012 to get to the conclusion that the selected nine Asian countries were strongly integrated with each other utilising wavelet multiple correlation. Dasgupta (2014) investigated the link between the BRIC stock markets and noticed a bidirectional causal relationship among selected stock markets. Due to its strong effect on both Russian and Brazilian stock markets, the researcher also determined that the Indian stock market was top among BRICS stock markets.

Singh and Singh (2016) used data from $1^{\text {st }}$ January (2004) to $30^{\text {th }}$ November (2014) to determine the link between the US and BRIC stock markets throughout the pre- and post-crisis periods, and 
discovered long-run causal movement during both periods. Prakash et al. (2017) used monthly data for 9 years from 2005 to demonstrate a link between the BRICS stock market but no causation was found. Again, in the study of Irshad and Palaniappan (2017), no long-run interdependency has been observed in the BRICS stock market considering data for ten years starting from January 2005 to November 2015. Pereira (2018) examined daily stock market data from 2003 to 2013 to see how the two popular stock market crises affected the BRICS stock market and concluded that the shock was significantly different in the period of disaster rather than in the normal time. During the period of COVID-19, Zeren and Hizarci (2020), Ashraf (2020), Senol and Zeren (2020) opine an enhancement of the share market volatility. During a coronavirus outbreak, the financial markets of Asian nations respond more adversely than non-Asian stock markets, according to Liu et al. (2020).

\subsection{Research Gap}

It has been observed in the earlier literature that the researchers showing their intense interest to find out the relationship as well as tested volatility in the stock market performance. A little amount of study was also carried out to determine the influence of any crisis time on stock market performance. However, a particular study on the BRICS stock market to determine volatility and relationships during the 2020 crisis era is difficult to come by.

\subsection{Problem Statement}

Currently, stock market performance depicts to worldwide integration, which advocates that by rising foreign contributors in the host economy, the stock market understandings growth forces in the economy ultimately play a significant position in stock market behaviour. Concurrently, it can be volatile and probabilistic although the stock market is related to main macroeconomic indexes of the economy. Because of the pandemic, investors are looking for a good return from the stock market and this basically is the driving force in the stock market activity. However, owing to increase of the COVID-19 cases and total or partial cessation of manufacturing and distribution, the stock market's energetic power tends to dwindle day by day. During the period of COVID-19, the financial market integration has fashioned gigantic interest among researchers, financial experts, and policymakers in identifying how financial blows are passed on the markets. Consequently, the strong economic binds among BRICS markets turn into the player of contagion.

\subsection{Need of the Study}

It has been noticed that BRICS have participated a vital position in the international economy after the crisis of 2008 as the major driving force. During this period, the world's average GNP per capita fell to $1.7 \%$ (based on \$PPPs-2005), whereas the BRICS' average GNP per capita was 5.4 percent. It is also predicted that BRICS' GNP per capita would grow at a rate of 4.5 percent between 2023 and 2030, which will be greater than the global GNP per capita (McKinley, 2018). The stock market integration gives potential benefits through global diversification. Also, the interconnection among global stock markets bounds the likelihood of advantages through international diversification. The logic is that there are lots of stock markets that trade dynamically on most important stock markets (Agarwal and Raja, 2018). 
Using the GARCH and EGARCH models of assessing volatility, this study examines the comovement of BRICS stock market volatility during the outbreak of COVID-19.

\section{Objective and Hypotheses of the Study}

\subsection{Objective of the Study}

The main objective of the study is:

- To examine the volatility and interrelation among BRICS stock markets in the period of pandemic.

\subsection{Hypotheses of the Study}

Following hypotheses haves been formed to analyse the study:

$\mathrm{H}_{01}$ : BRICS stock market affected (not affected) due to the existence of volatility.

$\mathrm{H}_{02}$ : BRICS stock market related (not related) with each other.

\section{Research Methodology}

\subsection{Data and Sample}

The first instance of COVID-19 was discovered on November 17, 2019. This research uses daily BRICS stock market data from November 18, 2019 to February 1, 2021 that has been obtained from Yahoo Finance database.

\subsection{Augmented Dickey Fuller Unit Root Test}

This unit root test is utilized in the share price data to ensure that the data set is stationary. A time series data is considered as stationary, which means that the mean, variance, and autocorrelation form remain stable throughout time. The ADF test was used in this case, where a null hypothesis was inferred due to the presence of a unit-root.

$\mathrm{H}_{0}=\mathrm{A}$ unit root is present.

$$
\Delta y_{t}=\propto_{0}+\theta \mathrm{y}_{\mathrm{t}-1}+\Delta y_{t}+e_{t}
$$

[y stands for time series; $t$ stands for time period; $\mathrm{n}$ stands for no. of lags, $\alpha_{0}$ stands for constant, and e stands for error term]

\subsection{GARCH Model}

In comparison to an ARCH model, a GARCH model has a lower parameter. The adoption of the GARCH model has turn into the volatility theory in time series data as a consequence of its frequent demonstration of providing more accurate findings.

The GARCH model $(a, b)$ can be characterised as $\sigma_{t}^{2}=\omega+\sum_{i=1}^{a} \sigma_{i} \xi^{2}+\sum_{j=1}^{b} \beta_{i} \sigma_{i-j}^{2}$

Larger numbers $\alpha$ indicate more responsiveness to new knowledge, whereas higher values $\beta$ indicate a longer period for the change to subside. $(\alpha+\beta)$ is a metric of the tenacity of the appropriate time 
series; hence, bigger values for $(\alpha+\beta)$ ought to be closer to one and imply more influence of the independent variable.

\subsection{EGARCH Model}

EGARCH model is used for recognizing the leverage effect through a generalized exponential distribution. The equation can be represented as follows:

$$
\log \sigma_{t}^{2}=\omega+\sum_{i=1}^{p} \beta_{i} \log \sigma_{i-1}^{2}+\sum_{j-1}^{p} \sigma_{t},\left\{\left|\xi_{t-1}\right| \sigma_{i-j}\right\}+\sum_{i=1}^{p} \gamma_{i}\left(\xi_{t-i} / \sigma_{t-j}\right) .
$$

To provide a variety of impacts on volatility, the model adds positive and negative values of $\varepsilon_{\mathrm{t}}$.

Because the value of $\left|\xi_{t-i} / \sigma_{j-i}\right|$ is blended with the coefficients $\gamma_{i}$ the EGARCH model is asymmetrical. Potential benefits have less instability than adverse effects since the exponent is generally negative, and most other findings seem to be the same.

\section{Data Analysis}

\subsection{Descriptive Analysis}

The descriptive data of the BRICS stock markets in the COVID-19 eruption are shown in Table 1. The finding indicates that Brazil's risk is significantly higher followed by India, Russia, South Africa and China, and there is a negative skewness in all of the BRICS stock markets studied. Jarque-Bera statistics' likelihood accepts the alternative hypothesis of non-normally distributed returns and confirms that some stock markets are not normally distributed. It thus suggests that perhaps the GARCH model is a good fit for estimating stock market volatility (Tripathi, 2017).

Table 1: Descriptive Analysis

\begin{tabular}{lccccc}
\hline & Brazil & Russia & India & China & South Africa \\
\hline Mean & 11.52 & 7.97 & 10.56 & 8.05 & 10.91 \\
SD. & 0.15 & 0.09 & 0.13 & 0.08 & 0.09 \\
Skewness & -0.86 & -0.51 & -.050 & -0.01 & -1.54 \\
Jarque-Bera & 36.93 & 18.42 & 12.77 & 22.18 & 256.51 \\
Probability & 0.00 & 0.00 & 0.00 & 0.00 & 0.00 \\
Observations & 295 & 299 & 304 & 296 & 302 \\
\hline
\end{tabular}

Source: Authors' Calculation

\subsection{Correlation Test}

Table 2 confirms that during the emergence of the COVID-19, the BRICS stock markets were positively linked with one another. Almost all the stock markets are highly correlated except China. However, this conclusion does not address the causal relationships among BRICS stock markets. 
Market Volatility and Causal Relationship among BRICS Stock Markets

Table 2: Correlation Test

\begin{tabular}{lccccc}
\hline & Brazil & Russia & India & Cbina & South Africa \\
\hline Brazil & 1.00 & & & & \\
Russia & 0.91 & 1.00 & & & \\
India & 0.86 & 0.82 & 1.00 & & \\
China & 0.57 & 0.65 & 0.66 & 1.00 & \\
South Africa & 0.90 & 0.89 & 0.84 & 0.68 & 1.00 \\
\hline
\end{tabular}

Source: Authors' Calculation

\subsection{ADF Unit Root Test Results}

The ADF t-statistic (table 3) of the BRICS stock indexes at level is smaller than the critical value at $5 \%$ and can be concluded as non-stationary. But BRICS stock market indices are stationary at $1^{\text {st }}$ difference as the test statistic of such stock indexes is larger than the critical value at $5 \%$.

Table 3: Unit Root Test Results

\begin{tabular}{|c|c|c|c|c|c|c|}
\hline \multirow[t]{2}{*}{ Variables } & \multicolumn{3}{|c|}{ At Level } & \multicolumn{3}{|c|}{ At $1^{s t}$ Differenced } \\
\hline & ADF stat & C.V. at $5 \%$ & Decision & ADF stat & C.V. at $5 \%$ & Decision \\
\hline Brazil & $\begin{array}{l}-1.18 \\
(0.91)\end{array}$ & -3.43 & NS & $\begin{array}{c}-22.51 \\
(0.00)\end{array}$ & -3.43 & S \\
\hline Russia & $\begin{array}{l}-1.59 \\
(0.79)\end{array}$ & -3.43 & NS & $\begin{array}{c}-16.96 \\
(0.00)\end{array}$ & -3.43 & S \\
\hline India & $\begin{array}{l}-1.34 \\
(0.87)\end{array}$ & -3.43 & NS & $\begin{array}{c}-19.57 \\
(0.00)\end{array}$ & -3.43 & S \\
\hline China & $\begin{array}{l}-2.39 \\
(0.38)\end{array}$ & -3.43 & NS & $\begin{array}{r}-16.25 \\
(0.00)\end{array}$ & -3.43 & S \\
\hline South Africa & $\begin{array}{l}-1.86 \\
(0.66)\end{array}$ & -3.43 & NS & $\begin{array}{c}-17.96 \\
(0.00)\end{array}$ & -3.43 & S \\
\hline
\end{tabular}

ADF: Augmented Dickey Fuller; C.V.: Critical Value; NS: Non-Stationary; S: StationaryFigures in Parenthesis denote MacKinnon (1996) one-sided p-values.

Source: Authors' Calculation

\subsection{Lag Length Selection}

For further tests, it is really necessary now to figure out the optimal lag period. Three major information criteria, i.e. AIC, SIC, and HQC are taken into account in this analysis to assess the right lag duration. To determine the best lag duration in our model, we use a maximum lag order of 8 (Yaman and Bhunia, 2018). Table 4 shows that because the SIC value is smaller than all information criteria; the ideal lag period is 1. 
Soumya Ganguly and Amalendu Bhunia

Table 4: Selection of Lag Length

\begin{tabular}{lcclll}
\hline Lag & LogL & LR & AIC & SIC & HQC \\
\hline 0 & 2055.53 & NA & -14.29 & -14.23 & -14.26 \\
1 & 3856.38 & 3526.40 & -26.66 & $-26.28^{*}$ & -26.51 \\
2 & 3915.91 & 114.51 & -26.91 & -26.20 & -26.62 \\
3 & 3960.76 & 84.70 & -27.04 & -26.02 & -26.63 \\
4 & 4019.50 & 108.88 & -27.28 & -25.94 & -26.74 \\
5 & 4078.40 & 107.12 & -27.51 & -25.86 & $-26.85^{*}$ \\
6 & 4110.95 & 58.07 & $-27.57^{*}$ & -25.59 & -26.78 \\
7 & 4129.76 & 32.90 & -27.52 & -25.23 & -26.60 \\
8 & 4154.30 & $42.08^{*}$ & -27.52 & -24.91 & -26.47 \\
\hline
\end{tabular}

Source: Authors' Calculation

\subsection{GARCH Analysis Upshot}

Table 5 shows the daily BRICS index GARCH test results over the pandemic era of the BRICS stock markets. Following China, Russia, South Africa, India, and Brazil, the score of á is quite high, indicating a heightened receptivity to new evidence. Furthermore, the score of â is substantial in Brazil, implying that the shift will take a bit longer to recede.

Table 5: GARCH Results

\begin{tabular}{lccccc}
\hline & Brazil & Russia & India & China & South Africa \\
\hline$\omega$ (constant) & 9.54 & 6.14 & 5.67 & 9.27 & 0.00 \\
& $(0.00)$ & $(0.00)$ & $(0.04)$ & $(0.01)$ & $(0.00)$ \\
$\alpha$ (arch effect) & 0.46 & 0.93 & 0.77 & 1.00 & 0.88 \\
& $(0.00)$ & $(0.00)$ & $(0.00)$ & $(0.00)$ & $(0.00)$ \\
$\beta$ (garch effect) & 0.54 & 0.14 & 0.34 & 0.06 & 0.11 \\
& $(0.00)$ & $(0.11)$ & $(0.00)$ & $(0.47)$ & $(0.28)$ \\
$\alpha+\beta$ & 1.00 & 1.07 & 1.11 & 1.06 & 0.99 \\
\hline
\end{tabular}

Source: Authors' Calculated Figures in parenthesis indicate probability

\subsection{EGARCH Analysis Upshot}

For observing the unequal influence of information and cognition on volatility and leverage, the EGARCH $(1,1)$ method is appropriate. The characteristics of the leverage effect is described by the negative gamma $(\gamma)$ [should be significant at $5 \%$ ] in the model, which shows that optimistic news have less shock on the endogenous variable. 
Market Volatility and Causal Relationship among BRICS Stock Markets

Table 6: EGARCH Results

\begin{tabular}{|c|c|c|c|c|c|}
\hline & Brazil & Russia & India & China & South Africa \\
\hline \multirow[t]{2}{*}{$\omega($ constant $)$} & -1.73 & -1.68 & -1.75 & -2.43 & -1.99 \\
\hline & $(0.00)$ & $(0.00)$ & $(0.00)$ & $(0.00)$ & $(0.00)$ \\
\hline \multirow[t]{2}{*}{$\alpha$ (arch effect) } & 0.90 & 0.87 & 1.21 & 1.15 & 1.06 \\
\hline & $(0.00)$ & $(0.00)$ & $(0.00)$ & $(0.00)$ & $(0.00)$ \\
\hline \multirow[t]{2}{*}{$\beta$ (garch effect) } & -0.03 & 0.00 & 0.07 & 0.00 & 0.01 \\
\hline & $(0.70)$ & $(0.93)$ & $(0.50)$ & $(0.97)$ & $(0.91)$ \\
\hline$\alpha+\beta$ & 0.87 & 0.87 & 1.28 & 1.15 & 1.07 \\
\hline \multirow[t]{2}{*}{$\gamma($ leverage effect $)$} & 0.84 & & & & \\
\hline & $(0.00)$ & $0.87(0.00)$ & $0.89(0.00)$ & $0.77(0.00)$ & $0.84(0.00)$ \\
\hline
\end{tabular}

Source: Authors' Calculated Figures in parenthesis indicate probability

During the epidemic, the gamma value is positive and statistically significant in BRICS stock markets. This implies no leverage effect has been found in the BRICS stock markets in times of COVID spread.

\subsection{Johansen Cointegration Test Results}

We can apply the Johansen cointegration approach since the picked variables have no unit root at the first difference. This is beneficial regardless of how much the factors have any long-run affiliation among the variables. The cointegration vectors may be determined using two likelihood ratios, the Trace test and the Maximum Eigen-Value test. Based on the SIC value, we utilised a linear deterministic trend with lag length 1 .

Table 7: Test Results of Johansen Cointegration Model

\begin{tabular}{|c|c|c|c|c|}
\hline \multicolumn{5}{|c|}{ Unrestricted Cointegration Rank Test (Trace) } \\
\hline $\begin{array}{l}\text { Hypothesized } \\
\text { No. of CE(s) }\end{array}$ & $\begin{array}{l}\text { Eigen value } \\
\text { Statistic }\end{array}$ & $\begin{array}{c}\text { Trace } \\
\text { Statistic }\end{array}$ & $\begin{array}{l}\text { C. V.at } \\
5 \%\end{array}$ & Probability $^{* *}$ \\
\hline None ${ }^{*}$ & 0.313516 & 196.2323 & 79.34145 & 0.0000 \\
\hline At most $1 *$ & 0.160505 & 86.01387 & 55.24578 & 0.0000 \\
\hline At most 2 & 0.072488 & 34.75223 & 35.0109 & 0.0533 \\
\hline At most 3 & 0.036084 & 12.70408 & 18.39771 & 0.2599 \\
\hline At most 4 & 0.006586 & 1.936065 & 3.841466 & 0.1641 \\
\hline \multicolumn{5}{|c|}{ Unrestricted Cointegration Rank Test (Maximum Eigenvalue) } \\
\hline $\begin{array}{l}\text { Hypothesized } \\
\text { No. of CE(s) }\end{array}$ & $\begin{array}{l}\text { Eigen value } \\
\text { Statistic }\end{array}$ & $\begin{array}{c}\text { Max-Eigen } \\
\text { Value Statistic }\end{array}$ & $\begin{array}{l}\text { C. V.at } \\
5 \%\end{array}$ & Probability $^{* *}$ \\
\hline None $*$ & 0.313516 & 110.2184 & 37.16359 & 0.0000 \\
\hline At most $1 *$ & 0.160505 & 51.26164 & 30.81507 & 0.0000 \\
\hline
\end{tabular}

Orissa Journal of Commerce, 42(3) (C) 2021 
Soumya Ganguly and Amalendu Bhunia

\begin{tabular}{lcccc}
\hline $\begin{array}{l}\text { Hypothesized } \\
\text { No. of CE(s) }\end{array}$ & $\begin{array}{c}\text { Eigen value } \\
\text { Statistic }\end{array}$ & $\begin{array}{c}\text { Max-Eigen } \\
\text { Value Statistic }\end{array}$ & $\begin{array}{c}\text { C. V. at } \\
5 \%\end{array}$ & Probability $^{* *}$ \\
\hline At most 2 & 0.072488 & 22.04814 & 24.25202 & 0.0952 \\
At most 3 & 0.036084 & 10.76802 & 17.14769 & 0.3303 \\
At most 4 & 0.006586 & 1.936065 & 3.841466 & 0.1641 \\
\hline
\end{tabular}

Trace test and Max-eigenvalue test indicates 2 cointegration eqn(s) at 5\% level. *denotes rejection of the hypothesis at the 0.05 level. **MacKinnon-Haug-Michelis (1999) p-values

Source: Authors' Calculation
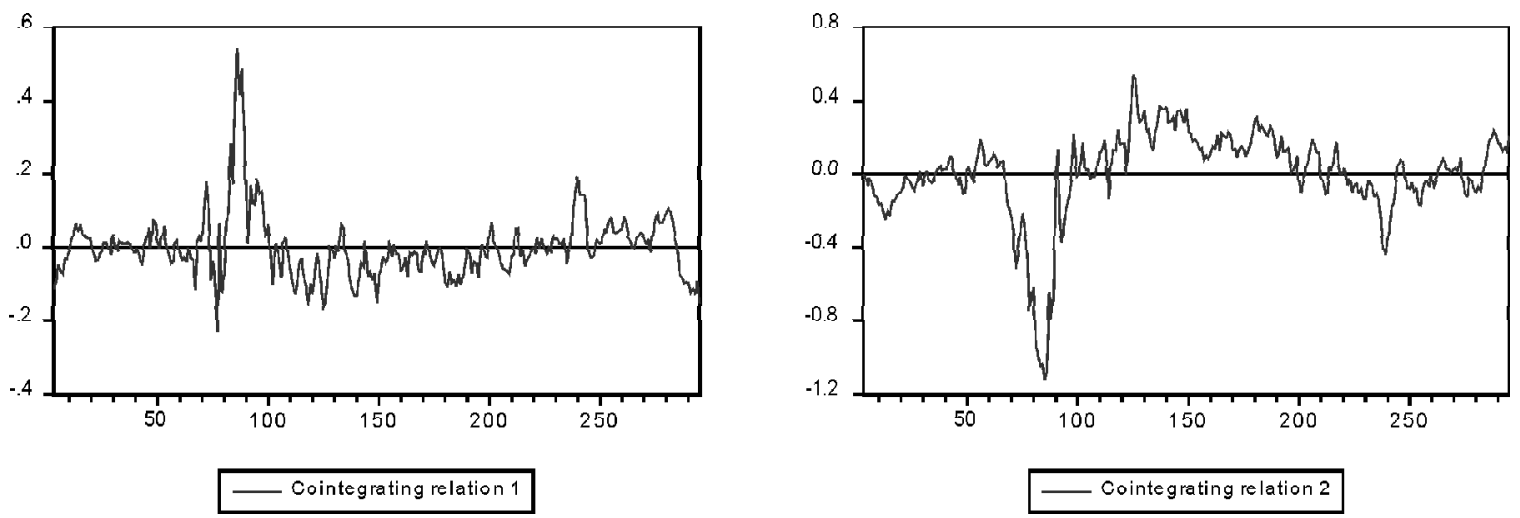

Figure 2: Cointegration Graph

Source: Authors' Calculation through EViews

The findings demonstrate that in the event of $r=0$ and $r e " 1$, both the likelihood ratios are greater than the C.V. at 5\% significant level, implying two cointegration equations at 5\% significant level. In addition, both graphs show the equal impression. This indicates that the BRICS stock markets have a long-term cointegration connection. Then, in the long term, it's important to see if there's any causation going from one to another equity market. The result indicates the utilisation of the VECM for this.

\subsection{Vector Error Correction Model Test Results}

The unit root test results reveals that the data set of BRICS is stationary at the 1 st difference but happens to non-stationary at level. Furthermore, the series is included into the same sequence. The Johansen cointegration test reveals that all series are cointegrated using two cointegration equations, which is statistically significant at 0.05 . For this model, VECM with lag 1 as per on SIC is feasible. 
Market Volatility and Causal Relationship among BRICS Stock Markets

Table 8: Test Results of VEC Model

\begin{tabular}{|c|c|c|c|c|c|}
\hline ECM: & D(Brazil) & $D$ (Russia) & $D$ (India) & $D$ (China) & $D$ (South Africa) \\
\hline Cointegration Equation 1 & .009911 & .057434 & .056659 & .031169 & .142197 \\
\hline Std. Error & -.02881 & -.0167 & -.01876 & -.01405 & -.01723 \\
\hline t-statistic & .34401 & 3.43903 & 3.01971 & 2.21898 & 8.25232 \\
\hline Prob. & 0.7309 & 0.0004 & 0.0031 & 0.0292 & 0.0000 \\
\hline Cointegration Equation 2 & .006178 & .011049 & .053248 & .014387 & .045676 \\
\hline Std. Error & -.01034 & -.006 & -.00674 & -.00504 & -.00619 \\
\hline t-statistic & 0.59725 & 1.84264 & 7.90429 & 2.85276 & 7.38305 \\
\hline Prob. & .5504 & .0618 & .0000 & .0046 & .0000 \\
\hline $\mathrm{D}$ (Brazil)-1 & -.267871 & .114606 & -.089653 & .048387 & -.06573 \\
\hline Std. Error & -.06281 & -0.03641 & -.04091 & -.03062 & -.03757 \\
\hline t-statistic & -4.26493 & 3.14772 & -2.1917 & 1.58007 & -1.74974 \\
\hline Prob. & .0000 & .0019 & .0317 & .1059 & .0849 \\
\hline D(Russia)-1 & .492385 & -.08669 & .107354 & -.05257 & .168948 \\
\hline Std. Error & -.10452 & -.06059 & -.06807 & -.05096 & -.06251 \\
\hline t-statistic & 4.71108 & -1.43082 & 1.57712 & -1.03161 & 2.70263 \\
\hline Prob. & .0000 & .1463 & .1095 & .3088 & .0066 \\
\hline D(India)-1 & .155502 & -.060398 & -.124858 & -.024236 & .00974 \\
\hline Std. Error & -.0801 & -.04643 & -.05217 & -.03906 & -.04791 \\
\hline t-statistic & 1.94129 & -1.3007 & -2.39332 & -.62054 & .2033 \\
\hline Prob. & .0524 & .2041 & .0151 & .5184 & .8569 \\
\hline $\mathrm{D}$ (China)-1 & .020981 & .137635 & .021645 & .036055 & -.03899 \\
\hline Std. Error & -.12036 & -.06977 & -.07839 & -.05869 & -.07199 \\
\hline t-statistic & .17431 & 1.9726 & .27612 & .61437 & -.5416 \\
\hline Prob. & .8616 & .0471 & .7926 & .5445 & .5815 \\
\hline $\mathrm{D}$ (South Africa)-1 & -.028739 & .032183 & -.354436 & -.024387 & -.11539 \\
\hline Std. Error & -.08993 & -.05213 & -.05857 & -.04385 & -.05379 \\
\hline t-statistic & -.31958 & .61736 & -6.05173 & -.55619 & -2.14539 \\
\hline Prob. & 0.7493 & .5375 & .0000 & .5783 & .0319 \\
\hline $\mathrm{C}$ & $8.23 \mathrm{E}-05$ & .000434 & .000818 & .000602 & .000384 \\
\hline Std. Error & -.00146 & -.00085 & -.00095 & -.00071 & -.00087 \\
\hline t-statistic & .05632 & .51286 & .85933 & .84517 & .43921 \\
\hline Prob. & .9551 & .6355 & .366 & .3806 & .639 \\
\hline
\end{tabular}

Source: Authors' Calculation

\section{Results and Discussion}

GARCH influences are favourable and substantial (other than that of China) throughout all stock markets all across the study period, with ultrahigh GARCH influences in the stock market of Brazil 
and low GARCH influences in the stock market of China. In the GARCH $(1,1)$ system, the turbulence is calculated as the sum of a and $\hat{a}$ and it spans between 0.99 and 1.11 throughout the COVID-19 study period during such pandemic. The test findings indicate that BRICS stock markets had more instability during the pandemic era. This demonstrates that even a pattern of unpredictability, which would be continue to maintain over time, might expose the fragility of equity prices. So, BRICS stock markets are more unpredictable during the COVID-19 initial days of pandemic period.

During the coronavirus outbreak as per the study period, the sum of $\alpha$ and $\beta$ (Table 6 ) in the EGARCH model varied from 0.87 to 1.28 . It has been proven that when the total combined value of á and â exceeds 1, there are more ARCH and GARCH shock absorbers on uncertainty, and conditional variance is also unpredictable. The combined value of á and â is greater than 1 in Chinese, Indian, and South African stock markets under study. The result reveals the reality of ARCH and GARCH shock on instability and it has also been noted that the conditional variance is also volatile. The VECM test results (table 8) corroborate the non-existence of long-term interdependence among BRICS stock markets under study. No long-run connectivity among the BRICS stock market has been found because of the statistically insignificant probability in both the cointegration equations. But short-run connectivity flowing from all the BRICS stock market other than Brazil has been noted due to positive and significant probability of the coefficient in both the cointegration equations.

\section{Conclusion}

This study investigates the volatility and connection of the BRICS stock market indexes in the longand short-term during the pandemic period. The Brazilian and Indian stock markets were the most unstable throughout the study period, according as per the value of standard deviation under descriptive statistics. The findings of the GARCH test reveal that ARCH and GARCH consequence are greater in BRICS stock markets. Accordingly, investors' decisions may be affected in BRICS stock markets. The spill over effect does not emerge in BRICS stock markets as the EGARCH result suggests. So it can be concluded that although their prevails volatility in BRICS stock markets due to the emergence of COVID19, but no leverage effect has been observed under study. The finding of the VECM reveal only shortrun causality in the BRICS stock market other than Brazil and no long-run causality has been found. Ultimately, it may be inferred that the negative news of the pandemic caused has a greater influence on stock indexes.

The shareholders in BRICS stock markets must take proper precaution to safeguard their existing investment by taking any diversification strategy. The prospective investors must aware the additional volatility inherent in BRICS stock markets as suggested in the study. The result could have been different and important if more affected countries are considered along with a comparative analysis of pre and during the outbreak of COVID-19. Another important area that covers the comparison of pre- pandemic and during-pandemic has not been considered that may be the future scope of the research in this field.

\section{References}

Agarwal, S. \& Raja, A. (2018). Stock market interlinkages among the BRIC economies. International Journal of Ethics and System. Retrieved on November 14, 2021 from https://doi.org/10.1108/IJOES-04-2018-0064. 
Market Volatility and Causal Relationship among BRICS Stock Markets

Ashraf, B.N. (2020). Stock markets' reaction to COVID-19. Retrieved on February 25, 2021 from http:// dx.doi.org/10.2139/ssrn.3585789.

Bakhshi, P., \& Chaudhary, R. (2020). Responsible Business Conduct for the Sustainable Development Goals: Lessons from Covid-19. International Journal of Disaster Recovery and Business Continuity, 11(1), 2835-2841. Retrieved on March 24, 2021 from http://sersc.org/journals/index.php/IJDRBC/article/view/29528.

Bryner, J. (2020, March 14). 1st known case of coronavirus traced back to November in China. Retrieved on October 16, 2020, from https:/ / www.livescience.com/first-case-coronavirus-found.html.

Cambre, M. D. (2020). How the stock market has performed during past viral outbreaks, as coronavirus virus spreads to Italy and Iran. Retrieved on December 12, 2020 from https://www.marketwatch.com/story/ heres-how-the-stock-market-has-performed-during-past-viral-outbreaks-as-chinas-coronavirus-spreads-202001-22.

Dasgupta, R. (2014). Integration and Dynamic Linkages of the Indian Stock Market with Bric - An Empirical Study, Asian Economic and Financial Reviem, 4(6), 715-731. Retrieved on September 28, 2020 from https:// ideas.repec.org/a/asi/aeafrj/v4y2014i6p715-731id1198.html.

Hashmi, F. (2020). Economic Decline Reversal Vital For BRICS As Long Recession Could Undermine Growth - NDB. Retrieved on January 21, 2021 from: https://www.urdupoint.com/en/business/economic-declinereversal-vital-for-brics-as-989148.html.

Ichev, R., \& Marinc, M. (2018). Stock Prices and Geographic Proximity of Information: Evidence from the Ebola Outbreak, International Review of Financial Analysis, 56, 153-166. Retrieved on December 3, 2021 from https://www.sciencedirect.com/sdfe/reader/pii/S1057521917301862/pdf.

Irshad, V. K. M., \& Palaniappan, S. V. (2017). Stock Market Integration among BRICS Nations - An Empirical Analysis (June 18, 2017). Retrieved on February 25, 2021 from: http://dx.doi.org/10.2139/ssrn.2988673.

Joshi, P. (2010). Modeling Volatility in Emerging Stock Markets of India and China. Journal of Quantitative Economics, The Indian Economic Society, 8(1), 86-94. Retrieved on July 30, 2020 from https://ideas.repec.org/a/jqe/ jqenew/v8y2010i1p86-94.html.

Joshi, S. S. (2013). Correlation and Co-integration of BRIC Countries' Stock Markets. Indian Journal of Finance, 7(4), 42-48. Retrieved on June 28, 2020 from http://www.indianjournaloffinance.co.in/index.php/IJF/article/ view/72131.

Larionova, M. (2020). Role of BRICS in the Global Economy, International Affairs. Retrieved on February 25, 2021 from: http://www.nkibrics.ru/posts/show/5ecfd0a66272691715a70000.

Liu, H. U., Manzoor, A., Wang, C. Y., Zhang, L., \& Manzoor, Z. (2020). The COVID-19 outbreak and affected countries stock markets response. International Journal of Environmental Research and Public Health, 17(8), 1-19. Retrieved on January 3, 2021 from https://www.mdpi.com/1660-4601/17/8/2800/pdf.

Loh, E. (2006). The Impact of SARS on the Performance and Risk Profile of Airline Stocks, International Journal of Transport Economics, 33(3), 401-422. Retrieved on December 17, 2020 from https://www.jstor.org/stable/ 42747811.

MacKinnon, J. G. (1996). Numerical distribution functions for unit root and cointegration tests. Journal of Applied Econometrics, 11(6), 601-618. Retrieved on December 19, 2020 from https:/ / www.jstor.org/stable / 2285154.

MacKinnon, J. G., Haug, A. A., \& Michelis, L. (1999). Numerical distribution functions of likelihood ratio tests for cointegration. Journal of Applied Econometrics, 14(5), 563-577. Retrieved on December 19, 2020 from https://www.jstor.org/stable/223206.

Orissa Journal of Commerce, 42(3) (C) 2021 
Soumya Ganguly and Amalendu Bhunia

McKinley, T. (2018). BRICS to Play a Leading Role in Driving Future Global Economic Growth, Institute for New Economic Thinking. Retrieved on February 25, 2021 from: https:/ /wwwineteconomics.org/perspectives/blog/ brics-to-play-a-leading-role-in-driving-future-global-economic-growth.

Nathan, N. (2020). Stock market hit by coronavirus virus: Reasons for turmoil, what equity investors should do now? Retrieved on February 25, 2021 from: https://economictimes.indiatimes.com/wealth/invest/stockmarket-hit-by-coronavirus-reasons-for-turmoil-what-equity-investors-should-do-now/articleshow/ $74623291 . \mathrm{cms}$.

Neokosmidis, I. (2009). Econometric Analysis of Realized Volatility: Evidence of Financial Crisis. Retrieved on February 25, 2021 from: http://www.lse.ac.uk/europeanInstitute/research/hellenicObservatory/pdf/ 4th_\%20Symposium/PAPERS_PPS/APPLIED_ECONOMICS/NEOKOSMIDIS.pdf.

Olowe, R.A. (2009). Stock Return, Volatility and the Global Financial Crisis in an Emerging Market: The Nigerian Case. International Review of Business Research Papers, 5(4), 426-447. Retrieved on January 15, 2021 from https:/ / citeseerx.ist.psu.edu/viewdoc/download?doi=10.1.1.570.8052\&rep=rep1\&type=pdf.

Pereira, D. R. C. (2018). Financial Contagion in the BRICS Stock Markets: An empirical analysis of the Lehman Brothers Collapse and European Sovereign Debt Crisis. Journal of Economics and Financial Analysis, 2(1), 1-44. Retrieved on December 19, 2020 from https://ideas.repec.org/a/trp/01jefa/jefa0011.html.

Prakash, J. V., Nauriyal, D. K., \& Kaur, S. (2017). Assessing Financial Integration of BRICS Equity Markets: An Empirical Analysis. Emerging Economy Studies, International Management Institute, 3(2), 127-138. Retrieved on September 17, 2020 from https://journals.sagepub.com/doi/abs/10.1177/2394901517730734.

Senol, Z., \& Zeren, F. (2020). Coronavirus (Covid-19) and stock markets: the effects of the pandemic on the global economy. Eurasian Journal of Researches in Social and Economics, 7(4), 1-16. Retrieved on January 19, 2021 from https://dergipark.org.tr/en/pub/asead/issue/54055/721871.

Sharma, G. D., Mahendru, M., \& Singh, S. (2013). Are the stock exchanges of emerging economies interlinked? : Evidence from BRICS. Indian Journal of Finance, 7(1), 26-37. Retrieved on February 25, 2021 from http:// www.indianjournaloffinance.co.in/index.php/IJF/article/view/72149.

Singh, A., \& Singh, M. (2016). Inter-linkages and causal relationships between US and BRIC equity markets: An empirical investigation. Arab Economic and Business Journal, 11(2), 115-145. Retrieved on January 24, 2021 from https://www.sciencedirect.com/sdfe/reader/pii/S2214462516300639/pdf.

Tiwari, A. K., Dar, A. B., Bhanja, N., \& Shah, A. (2013). Stock Market Integration in Asian Countries: evidence from Wavelet multiple correlations, Journal of Economic Integration, 28(3), 441-456. Retrieved on January 19, 2021 from https://www.e-jei.org/upload/JEI_28_3_441_456_2013600021.pdf.

Tripathi, N. (2017). Do BRIC countries stock market volatility move together? An empirical analysis of using multivariate GARCH models, International Journal of Business and Emerging Markets, 9(2), 104-123. Retrieved on January 19, 2021 from http://www.inderscience.com/offer.php?id=83353.

Wong, W. K., Penm, J., Terrell, R. D., \& Lim, K. Y. C. (2004). The relationship between stock markets of major developed countries and Asian emerging markets, Advances in Decision Science 8, 201-218. Retrieved on January 2, 2020 from https://downloads.hindawi.com/archive/2004/613545.pdf.

Yaman, D., \& Bhunia, A. (2018). Southeast Asian Tigers and Asia's Largest Economy: Investment and Diversification Opportunities. Journal of International Finance and Economics, 18(1), 45-60, http:/ /dx.doi.org/ 10.18374/JIFE-18-1.5.

Zeren, F., \& Hizarci, A. E. (2020). The impact of Covid-19 coronavirus on stock markets: evidence from selected countries. Muhasebe ve Finans Incelemeleri Dergisi, 3(1), 78-84. Retrieved on January 15, 2020 from https:// dergipark.org.tr/en/download/article-file/1024340. 